\title{
Relationship between the genetic structure of the Andean toad Rhinella spinulosa (Anura: Bufonidae) and the northern Chile landscape $\left(21^{\circ}-24^{\circ} \mathrm{S}\right)$

\author{
Relación entre la estructura genética del sapo andino Rhinella spinulosa \\ (Anura: Bufonidae) y el paisaje del norte de Chile $\left(21^{\circ}-24^{\circ} \mathrm{S}\right)$
}

\section{CAROLINA E. GALLARDO ${ }^{1}$, HECTOR J. HERNÁNDEZ ${ }^{2}$, JOSÉ A. F. DINIZ-FILHO ${ }^{3}$, R. EDUARDO PALMA ${ }^{4} \&$ MARCO A. MENDEZ1, *}

${ }^{1}$ Laboratorio de Genética y Evolución, Departamento de Ciencias Ecológicas, Facultad de Ciencias, Universidad de Chile, P.O. Box 653. Las Palmeras 3425, Ñuñoa, Santiago, Chile

${ }^{2}$ Laboratorio de Geomática y Ecología del Paisaje, Facultad de Ciencias Forestales, Universidad de Chile, P.O. Box 1004, Santa Rosa 11315, La Pintana, Santiago, Chile

${ }^{3}$ Departamento de Biologia Geral, ICB, Universidade Federal de Goiás, Cx.P. 131 Campus II 74001970, Goiânia, GO - Brasil ${ }^{4}$ Laboratorio de Biología Evolutiva, Departamento de Ecología y Centro de Estudios Avanzados en Ecología y Biodiversidad (CASEB), Facultad de Ciencias Biológicas, Pontificia Universidad Católica de Chile, Alameda 340, Santiago 6513677, Chile ${ }^{*}$ Corresponding author: mmendez@uchile.cl

\begin{abstract}
We analyzed the relationship of landscape and environmental features on the genetic differentiation of Rhinella spinulosa (Wiegmann, 1834) in the Altiplano of Antofagasta (Chile). We performed three types of analyses at different spatial scales: (1) Considering all populations; (2) Grouping populations by watershed and by sub-watershed; and (3) Using the results of a spatial analysis of molecular variation (SAMOVA). Landscape features were incorporated using Geographic Information Systems, with three hypothetical dispersal models: (1) Euclidean distance (null model); (2) Least cost based on wetland locations; and (3) Least cost based on least slopes. We also included differences in temperature, precipitation and altitude among localities. The Akaike information criterion was used to select the best model and the relative importance of each variable in the model was estimated with partial regressions. We found a high genetic differentiation among populations $\left(\mathrm{F}_{\mathrm{st}}=0.693\right)$ and isolation by distance $(\mathrm{r}=0.767)$. AMOVA showed that the watersheds explained $8.67 \%$ of the genetic variance and sub-watersheds $35.99 \%$. At the largest spatial scale, considering all populations, the model that best explained genetic differentiation included Euclidean distance, altitude and annual precipitation. At a smaller scale, in two of three sub-watersheds (Río San Pedro and Salar de Atacama) the genetic differentiation was best explained by landscape variables (principally temperature and altitude). At the smallest scale, considering those populations that have diverged recently detected by SAMOVA, the genetic differentiation was best explained by the wetland-based route and annual precipitation. This approach revealed the importance of landscape features in the colonization of $R$. spinulosa in this zone.
\end{abstract}

Key words: altiplano, amphibian, landscape genetics, least cost models, mtDNA.

\section{RESUMEN}

Se evaluó la relación entre las características del paisaje y ambientales y la diferenciación genética de Rhinella spinulosa en el altiplano de la Región de Antofagasta (Chile). Para esto se realizaron tres tipos de análisis a diferentes escalas espaciales: (1) considerando todas las poblaciones; (2) agrupando las poblaciones por cuencas y por subcuencas; y (3) utilizando los resultados del análisis espacial de variación molecular (SAMOVA). Las características del paisaje se incorporaron diseñando tres modelos hipotéticos de dispersión con los Sistemas de Información Geográfico: (1) distancia euclidiana (modelo nulo); (2) de menor costo basado en la localización de los humedales; y (3) de menor costo basado en las pendientes menores. Además, se incluyeron las diferencias en temperatura, precipitación y altitud entre localidades. Para seleccionar el modelo que mejor explicara la diferenciación genética se utilizó el Criterio de Información de Akaike y se estimó la importancia relativa de cada variable del modelo seleccionado utilizando regresiones parciales. Se encontró una alta diferenciación genética entre las poblaciones $\left(\mathrm{F}_{\mathrm{st}}=0.693\right)$ y un patrón claro de aislamiento por distancia $(\mathrm{r}=0.767)$. El análisis AMOVA mostró que las cuencas explicaron un $8.67 \%$ de la varianza genética y las subcuencas un $35.99 \%$. A mayor escala espacial, considerando todas las poblaciones, el mejor modelo que explicó la diferenciación genética incluyó las variables distancia euclidiana, altitud y precipitación anual. A menor escala, en dos de las tres subcuencas (Río San Pedro y Salar de Atacama) la diferenciación genética fue mejor explicada por variables del paisaje (temperatura y altitud, principalmente). A menor escala, considerando las poblaciones que han divergido recientemente detectadas por SAMOVA, la diferenciación genética fue mejor explicada por la ruta basada en humedales y la precipitación anual. Esta aproximación muestra la importancia de las características del paisaje en la colonización de $R$. spinulosa en esta zona.

Palabras clave: altiplano, anfibios, genética del paisaje, modelos de menor costo, mtDNA. 


\section{INTRODUCTION}

The interaction between landscape (e.g., slope) and environmental (e.g., temperature) features may strongly affect the dispersal and gene flow of organisms; it is essential to identify the biotic and/or abiotic factors involved in the differentiation of populations in order to model and predict the evolution of genetic diversity (Wiens 2001, Guillot et al. 2005). These factors may be quantified using Landscape Genetics, a research area that integrates population genetics, landscape ecology and spatial statistics. They also allow to describe spatial genetic patterns and the processes that can originate those patterns (Manel et al. 2003). Landscape genetics is studied in a spatially explicit metapopulation context, allowing to investigate the interaction between landscape features and spatial dispersal (Michels et al. 2001, Storfer et al. 2007, Diniz-Filho et al. 2008). Analyses that incorporate landscape variables in studies of population genetic structure represent a new approximation to the ecological causes of evolutionary patterns (Kozak et al. 2008). Therefore, Landscape Genetics has a promising potential in evolution, ecology and conservation biology studies (Manel et al. 2003).

To include the landscape component in landscape genetic studies, spatial analysis techniques from Geographic Information Systems have been used in order to model least-cost dispersal scenarios. A scenario is constructed by determining the accumulated movement cost of a species from one point to another through landscape features (i.e. topography, habitat type, cover type, etc.) that have an assigned value, creating a least-cost route. After the least-cost route is obtained a modified geographic distance is calculated, which is then correlated with the genetic distance found between studied populations (Spear et al. 2005, Storfer et al. 2007).

In landscape genetic analysis, the process of isolation by distance should be considered as the null model (Broquet et al. 2006). Therefore, deviation from the null model implies that other factors may be involved in the processes of genetic differentiation (Spear et al. 2005, Telles et al. 2007). For example, Michels et al. (2001) implemented a least-cost distance based on dispersal rates of zooplankton, and Clark et al. (2008) proposed a model of least cost for the rattlesnake Crotalus horridus based on the number of thermoregulation sites between hibernacula. In both cases, rather than simple Euclidian distance it was the least cost distance that showed a greater correlation with genetic distance. This can be explained by the fact that there is no available habitat between two sites in a straight line; therefore, the genetic differentiation cannot be explained by isolation by distance only (Koscinski et al. 2009). Likewise, the modeling of animal movement through a landscape can facilitate the interpretation of contemporary and historic genetic variation patterns (Koscinski et al. 2009).

Amphibians, due to their limited vagility, high philopatry (Seppä \& Laurila 1999) and spatially separated reproductive sites, constitute a good model for landscape genetic studies, since these factors may affect their dispersal and gene flow (Funk et al. 2005). In a study of the tiger salamander (Ambystoma tigrinum melanostictum), Spear et al. (2005) found that differences in altitude and distance between populations were the main factors that favored genetic differentiation, acting as barriers to dispersal and gene flow. On the other hand, Funk et al. (2005) found that mountains ridges and elevation differences between sites were associated with high levels of genetic differentiation between populations of Rana luteiventris. At the same time, high levels of gene flow were observed among low-altitude sites separated by large geographic distances.

Genetic studies on Rhinella spinulosa in northern Chile have shown two highly divergent lineages, which differed in their phylogeographic structure (Correa et al. 2010). Within the southern lineage, a group of populations located in the southeast part of the Salar de Atacama, showed the highest genetic divergence. Correa et al (2010) explained this pattern proposing a model of peripatric differentiation for these populations. Therefore, it would be interesting to evaluate the population genetic structure of this lineage, considering whether habitat features can shed light on the conditions that molded the genetic structure of these amphibian populations. The Andean landscape of northern Chile consists of arid and mountainous environments. In this type of landscape, streams are formed between steep slopes, creating potential sites for amphibian reproduction, which are distributed as small patches in landscape terms, 
generating substantial population structure between amphibian populations (Dayton \& Fitzgerald 2006). Additionally, in ectotherms it has been described that environmental variables (e.g., temperature, precipitation) may affect the evolution of many fundamental biological traits (i.e life history traits, dispersion and survival), promoting genetic divergence between populations (Kozak et al. 2008, Méndez \& Correa-Solis 2009). Therefore, our study addressed the following questions: what is the relative impact of landscape and environmental factors on the distribution of genetic diversity in $R$. spinulosa?. Which landscape features can affect dispersal and gene flow in this species? Do the differentiation patterns detected depend upon the spatial analysis used?. To address these questions, we analyzed 13 sampling sites from the Antofagasta region in northern Chile.

\section{METHODS}

\section{Study area}

The study area was located in the foothills of the Andes of northern Chile, characterized by a high-altitude desert climate (Castillo et al. 1997). Precipitation gradually increases with altitude being higher during summer seasons (December to March; Arroyo et al. 1988). Water reaches lower altitudes watersheds through runoff and percolation, sustaining low altitude regions with extreme aridity and permanent water deficit (Salazar 1997). The specific geographic location of the study sites were the foothill zones and the Puna area of Atacama in Antofagasta region (21-24 ${ }^{\circ} \mathrm{S}$; Fig. $1)$. These populations correspond to the southern lineage described in Correa et al. (2010). We sampled 203 individuals from 13 sampling sites (Table 1, Fig. 1). Each locality was geo-referenced using the WGS84 datum, UTM zone 19S. The specimens used in this study were stored in the Herpetological Collection of the Departamento de Biología Celular y Genética of the Universidad de Chile (DBGUCH), and were previously collected as part of other studies.

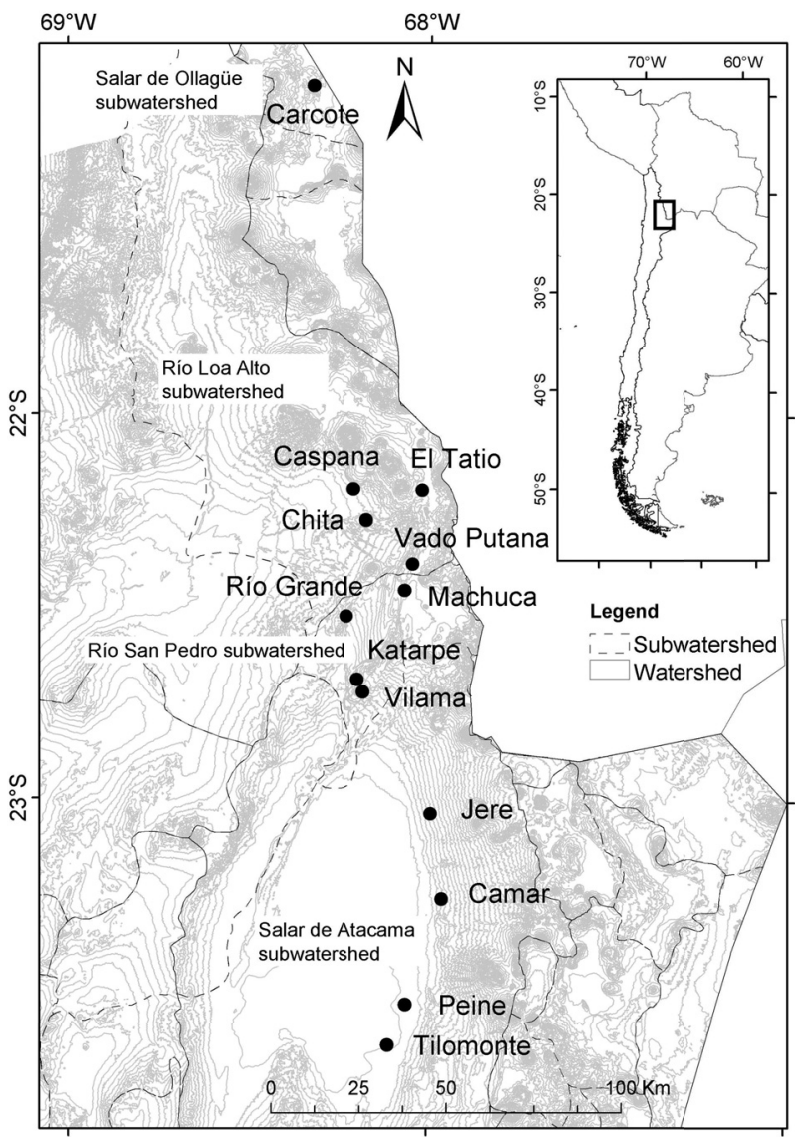

Fig. 1: Geographic location of the sampling areas within watersheds (solid lines) and within sub-watersheds (dotted lines) in the Antofagasta Region of Chile.

Ubicación geográfica de las áreas de muestreo dentro de cuencas (línea sólida) y dentro de subcuencas (línea punteada) en la Región de Antofagasta en Chile. 


\section{Study species}

$R$. spinulosa is an anuran whose distributional range extends from the Peruvian and the Bolivian Altiplano, to the southern Andes of Chile and Argentina. They inhabit zones near streams, lakes and high altitude wetlands, between 1000 and $4600 \mathrm{~m}$ (Cei 1962, Veloso \& Navarro 1988). Currently, there are few studies on the dispersal capacity or habitat use of this species. It is known that larvae and postmetamorphics are diurnal, whereas adults are nocturnal, resting under rocks during the day (Cei 1962, Lambrinos \& Kleier 2003). It has also been documented that adults are more terrestrial than aquatic forms (Cei 1962). Espinoza \& Quinteros (2008) reported that postmetamorphics are found always near water, moving a maximum of $1 \mathrm{~m}$ away from a pond, while Vidal (2009) established that they could move up to $15 \mathrm{~m}$. Phylogeographic studies performed on the distributional range of $R$. spinulosa in northern Chile, based on mitochondrial (Correa et al. 2010) and nuclear markers (Méndez et al. 2004), found a northern $\left(18-20^{\circ} \mathrm{S}\right)$ and a southern lineage $\left(21-24^{\circ} \mathrm{S}\right)$. The southern lineage had a greater structure, mainly due to the high divergence of the eastern springs populations of the Salar de Atacama (Correa et al. 2010).

\section{DNA extraction and sequencing}

We performed the extraction, amplification and sequencing of mitochondrial DNA (control region) using the procedures described by Correa et al. (2010). The sequences were edited and aligned using the BioEdit 7.0.9.0 software (Hall 1999). For multiple alignment of the edited sequences we used the Clustal W 1.4 software (Thompson et al. 1994) with default parameters, after which alignments were inspected visually.

\section{Genetic differentiation and structure}

Genetic differentiation was evaluated using pairwise $\mathrm{F}_{\mathrm{st}}$ distance values between all pairs of localities, using the Arlequin 3.11 software (Excoffier et al. 2005) with 10000 permutations. The existence of isolation by distance was evaluated by means of a Mantel test, which estimates the statistical significance between correlation matrices (Manly 1985). This test was performed with the $\mathrm{F}_{\mathrm{st}}$ and geographic distance matrices, using XLSTAT 2.03 software (Addinsoft 2009), with 10000 permutations. Indices of haplotype and nucleotide diversity were calculated using DNAsp 4.5 software (Rozas et al. 2003). Haplotype networks were obtained using the median joining network method (Bandelt et al. 1999), with the Network 4.5.1.0 software. The haplotypes for this analysis included the sites with indels which were informative, in order to separate populations.

To determine which of variables best explain the genetic differentiation at different spatial scales we performed three types of analyses: (1) At a large spatial scale, using all localities; (2) At a small spatial scale, grouping populations by watershed and by sub-

TABLE 1

Sampling localities, number of Rhinella spinulosa specimens utilized (n) in this study, altitude (meters above sea level), precipitation $(\mathrm{mm})$, temperature $\left({ }^{\circ} \mathrm{C}\right)$, UTM coordinates (Datum WGS84 19S) and watershed and sub-watershed names.

Localidades de muestreo, número de especímenes utilizados de Rhinella spinulosa (n) en el estudio, altitud (metros sobre el nivel del mar), precipitación (mm), temperatura $\left({ }^{\circ} \mathrm{C}\right)$, coordenadas UTM (Datum WGS84 19S) y nombres de las cuencas y subcuencas.

\begin{tabular}{lcccccccc}
\hline Watershed & Subwatershed & Locality & $\mathrm{n}$ & Altitude & $\begin{array}{c}\text { Annual mean } \\
\text { temperature }\end{array}$ & $\begin{array}{c}\text { Annual } \\
\text { precipitation }\end{array}$ & UTM E & UTM S \\
\hline $\begin{array}{l}\text { Fronterizas Salar } \\
\text { Michincha-Río Loa }\end{array}$ & Salar de Ollagüe & Carcote & 13 & 3688 & 6.7 & 60 & 570111 & 7661446 \\
Río Loa & Río Loa Alto & Caspana & 13 & 3245 & 9.5 & 34 & 581365 & 7545277 \\
Río Loa & Río Loa Alto & El Tatio & 19 & 4264 & 4.8 & 42 & 601129 & 7544953 \\
Río Loa & Río Loa Alto & Chita & 15 & 3741 & 7 & 36 & 584997 & 7536439 \\
Río Loa & Río Loa Alto & Vado Putana & 15 & 4286 & 4.7 & 41 & 598267 & 7523790 \\
Salar de Atacama & Río San Pedro & Machuca & 15 & 3979 & 6.1 & 38 & 596010 & 7516227 \\
Salar de Atacama & Río San Pedro & Río Grande & 10 & 3045 & 10.4 & 34 & 579237 & 7508817 \\
Salar de Atacama & Río San Pedro & Katarpe & 17 & 2460 & 12.8 & 40 & 582276 & 7490638 \\
Salar de Atacama & Río San Pedro & Vilama & 15 & 2579 & 12.9 & 42 & 583916 & 7486983 \\
Salar de Atacama & Salar de Atacama & Jere & 23 & 2513 & 12.6 & 46 & 603327 & 7451780 \\
Salar de Atacama & Salar de Atacama & Camar & 15 & 2727 & 12.4 & 44 & 606481 & 7427442 \\
Salar de Atacama & Salar de Atacama & Peine & 16 & 2440 & 13.7 & 44 & 596023 & 7397016 \\
Salar de Atacama & Salar de Atacama & Tilomonte & 17 & 2365 & 13.9 & 43 & 590772 & 7385283 \\
\hline
\end{tabular}


watershed, performing for this two Analyses of Molecular Variance (AMOVA) using Arlequin 3.11 software, with 10000 permutations, determining the genetic variance explained at the watershed and sub-watershed levels; and (3) Using the results of a spatial analysis of molecular variation (SAMOVA), without a priori structure (i.e. watershed, sub-watershed). For the SAMOVA analysis, which finds groups of contiguous localities that maximize the between-group variance determining the most probable genetic structure according to the number of groups entered by the user, we used the SAMOVA 1.0 software (Dupanloup et al. 2002).

\section{Landscape and environment variables}

\section{Wetland presence and slopes (dispersal routes)}

To incorporate landscape variables into the study (wetland presence and slopes) we created three types of probable dispersal routes between localities (Fig. 2) using the ArcGIS 9.2 software (ESRI 2006). These variables were represented in raster format. The first route was Euclidean distance (the null model). The second route used a least cost model based on high altitude wetlands, which in this area correspond to water courses and springs that depend upon the precipitation regime (Castillo et al. 1997). In the latter route, the cost of movement within wetlands was set to 0 , and outside of them it was set to 100 ; for this we used the wetlands vegetation cover created by Faúndez \& Escobar (2006). The value of 100 was chosen due to the habitats of $R$. spinulosa are distributed in patches, with no water sources among them, which would presumably inhibit their dispersal. The value 0 was chosen for dispersion inside wetlands, where it is more probable to find this species, taking also into consideration that there are no predators that could limit the movement of $R$. spinulosa inside the vegetation patches. The third type of route was also a least cost model, but based on slopes; the cost of movement from one pixel to another (friction) increased linearly with slope increase up to $45^{\circ}$. We used

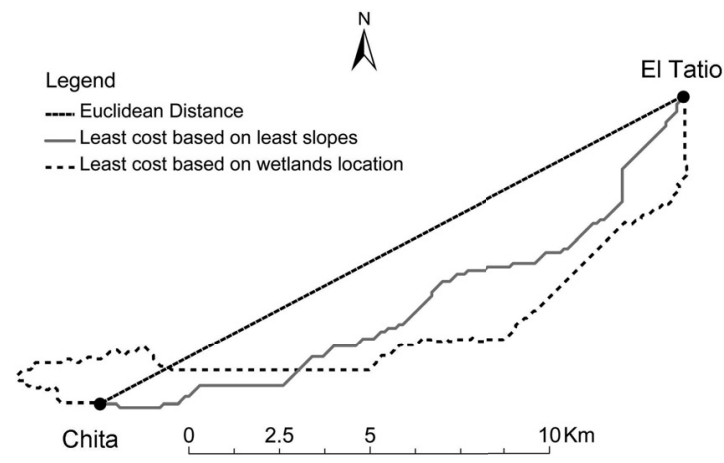

Fig. 2: Example of the three types of hypothetical dispersal routes created for Rhinella spinulosa between all localities. Routes between El Tatio and Chita localities are shown.

Ejemplo de los tres tipos de rutas hipotéticas de dispersión creadas para Rhinella spinulosa entre todas las localidades. Se muestran las rutas entre las localidades de El Tatio y Chita. the data of Shuttle Radar Topography Mission 90 m, available at http://srtm.csi.cgiar.org/.

\section{Altitude, temperature and precipitation}

The altitude of localities was obtained with GPS that included a barometric altimeter to measure altitude differences. This variable has been positively related with the genetic differentiation of amphibians (Funk et al. 2005, Spear et al. 2005). Temperature and precipitation data for the sites were obtained from the Worldclim dataset that includes climatic variables at $\sim 1$ $\mathrm{km}^{2}$ spatial resolution (Hijmans et al. 2005). Precipitation was included since its spatial distribution in the Altiplano is heterogeneous, with a latitudinal gradient decreasing from north to south (Aceituno 1997, Salazar 1997), and an altitudinal gradient that increases with altitude (Arroyo et al. 1988). Temperature was included because it has an important altitudinal and seasonal variation in the study area, with a mean that is relatively low, decreasing with altitude (Aceituno 1997). With the climatic variables we created Euclidean distance matrices between localities, using the NTSYSpc 2.10 software (Rohlf 2000), in order to include them in the evaluation and selection of the model that best explains the genetic differentiation.

\section{Criteria for selection of the best model}

To select the model which best explained the genetic differentiation among all possible combinations of variables, we used the Akaike Information Criterion (AIC). The AIC considers the fit of each model to an observed series as a function of the number of parameters utilized. Thus, it determines the combination of variables that best explains the observed data. The AIC of each model is transformed to a AIC, which is the difference between the AIC of a model and the minimum AIC value found in the set of models compared. A value of AIC greater than 7 indicates that the model has a relatively poor fit compared to the best model; a value less than 2 indicates that the model is equivalent to the minimum AIC (Burnham \& Anderson 2002). In this way, we were able to reduce the possible models to three candidate models, one for each route type, and then choose the best model among these three. Thus, we determined which route and which variables were most strongly related to the genetic data. The variables and routes that were not included in the selected models were excluded from the rest of the analyses. The analyses just described were performed with the SAM 3.0 software (Rangel et al. 2006).

\section{Best model variance partition}

Once the best model was selected, the amount of genetic differentiation explained by each variable was estimated using partial regressions. These analyses were performed with Statistica 6.0 (StatSoft Inc. 2001) and SAM 3.0 packages. Different studies have used regression analyses to evaluate hypotheses about the effects of spatial, temporal and environmental components on the genetic differentiation (Spear et al. 2005, Telles \& Diniz-Filho 2005, Broquet et al. 2006, Hull et al. 2008).

In a multiple regression analysis, variance partition is analogous to the correlation analyses between explanatory variables $(\mathrm{X} 1, \mathrm{X} 2, \mathrm{X} 3$, etc.) and the response variable $(Y)$. These analyses can be conceptually represented by a Venn diagram, as is commonly used 
in set theory, where the components are displayed as overlapping circles that correspond to the influence areas of the explanatory variables (Anderson \& Gribble 1998). This methodology allows evaluation of different groups of explanatory variables, considering their capacity to explain the observed patterns (Legendre \& Legendre 1998). Since the explanatory variables are usually not independent, this procedure can help to identify the influence of each component and their overlap effects on the dependent variable, clarifying the influence of the variables considered in the proposed model (Anderson \& Gribble 1998). However, this approach does not necessarily identify the causal factors; it simply facilitates the formulation of hypotheses about the processes which may have generated the observed patterns (Legendre \& Legendre 1998)

\section{RESULTS}

Analysis of sequences, genetic differentiation and genetic structure

We sequenced 203 specimens, obtaining 863 nucleotide sites, of which 31 sites were polymorphic and four had indels. We found 25 haplotypes including the sites with indels. Haplotype and nucleotide diversity per site were 0.85 and 0.00589 , respectively. All sequences were deposited in GenBank with accession numbers AY663485-AY663519; FJ643165-FJ643276 and FJ790426-FJ790434.

The genetic differentiation between all localities was high (global $\mathrm{F}_{\mathrm{st}}=0.693 ; \mathrm{P}=$ 0.001 ), with a wide variation range among populations (Table 2). The Mantel test revealed a significant pattern of isolation by distance $(\mathrm{r}=0.767, \mathrm{P}<0.001)$. The most differentiated localities were Carcote, Peine and Tilomonte (Table 2). These localities are in the northern and southern ends of the study area. Carcote is located at the north in a different subwatershed from the rest of the localities, 116 $\mathrm{km}$ from the closest other locality. Peine and Tilomonte are located in the south, in the Salar de Atacama sub-watershed. The genetic differentiation in the Río Loa Alto $\left(\mathrm{F}_{\mathrm{st}}=0.146\right.$; $\mathrm{P}=0.0005)$, and Río San Pedro $\left(\mathrm{F}_{\mathrm{st}}=0.120 ; \mathrm{P}\right.$ $=0.0145)$ sub-watersheds were much lower than the value for all populations. By contrast, differentiation within the Salar de Atacama subwatershed was high $\left(\mathrm{F}_{\mathrm{st}}=0.630 ; \mathrm{P}=0.0001\right)$.

The AMOVA showed that grouping populations by sub-watersheds explained more variation than grouping them by watersheds (Table 3). SAMOVA showed that maximum variance was obtained with four groups: (1)
Carcote; (2) Jere; (3) Peine and Tilomonte; (4) Caspana, El Tatio, Chita, Vado Putana, Machuca, Río Grande, Katarpe, Vilama and Camar (Table $3)$. This structure and relationship among haplotypes was also detected in the haplotype network, in which the Carcote locality had a unique haplotype; the Jere and Peine localities shared a different unique haplotype, but also had haplotypes from group 4 (Fig. 3, Table 5).

\section{Analyses at a large spatial scale (using all localities)}

\section{Best model selection}

The best model chosen by AIC using all localities was the one that included the variables Euclidean distance, altitude and annual precipitation (Table 4A). This model explained $64.6 \%$ of the genetic differentiation, $5.8 \%$ more than the Euclidean distance (null model). The variables altitude and annual precipitation were chosen in all candidate models for each route type. The wetland-based route had the greatest AIC value and explained the least amount of genetic variation.

\section{Best model variance partition}

According to the AIC, the best model included the predictive variables annual precipitation, altitude and Euclidean distance. We determined the contribution of each variable by relating the response variable $\left(\mathrm{F}_{\mathrm{st}}\right)$ to the predictive variables in a linear regression analysis; altitude, annual precipitation and distance had values of $0.09 \%, 17.64 \%$ and $58.82 \%$, respectively (Fig. 4A). Partial regressions showed that the greatest proportion of the differentiation was explained by the Euclidean distance alone $\left(r^{2}\right.$ $=46.5 \%)$ and the overlap of Euclidean distance and precipitation $\left(\mathrm{r}^{2}=16.6 \%\right)$. The overlap of the three variables of the model had a low value $(\mathrm{g}=0.88 \%)$. The overlaps of precipitation and altitude, and distance and altitude had low and negative values, probably due to the variables have opposite effects on genetic differentiation. It is important to indicate that, although altitude was one of the chosen variables, the regression analysis showed that there was no significant relation with genetic differentiation; therefore in this case it may not be a good predictive variable. 


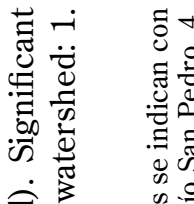

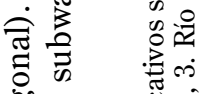

की

吾.

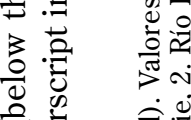

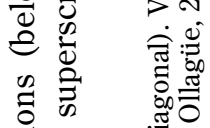

空

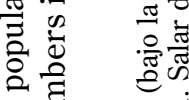

ह

芒

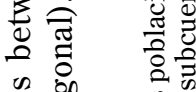

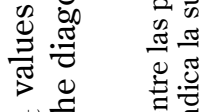

舟

(1)

\%

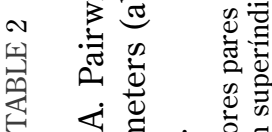

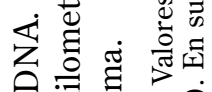

灵 氕

的要艺范

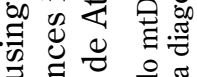

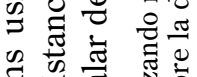

응 焉咅

胥

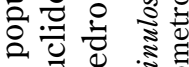

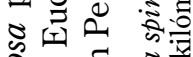

ङ

की

of को 8

壳

इ

Чั

흐릉요 웡

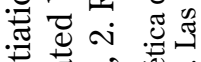

氖昰:

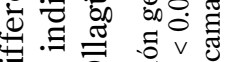

记

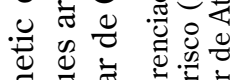

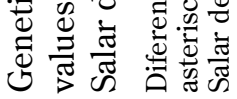

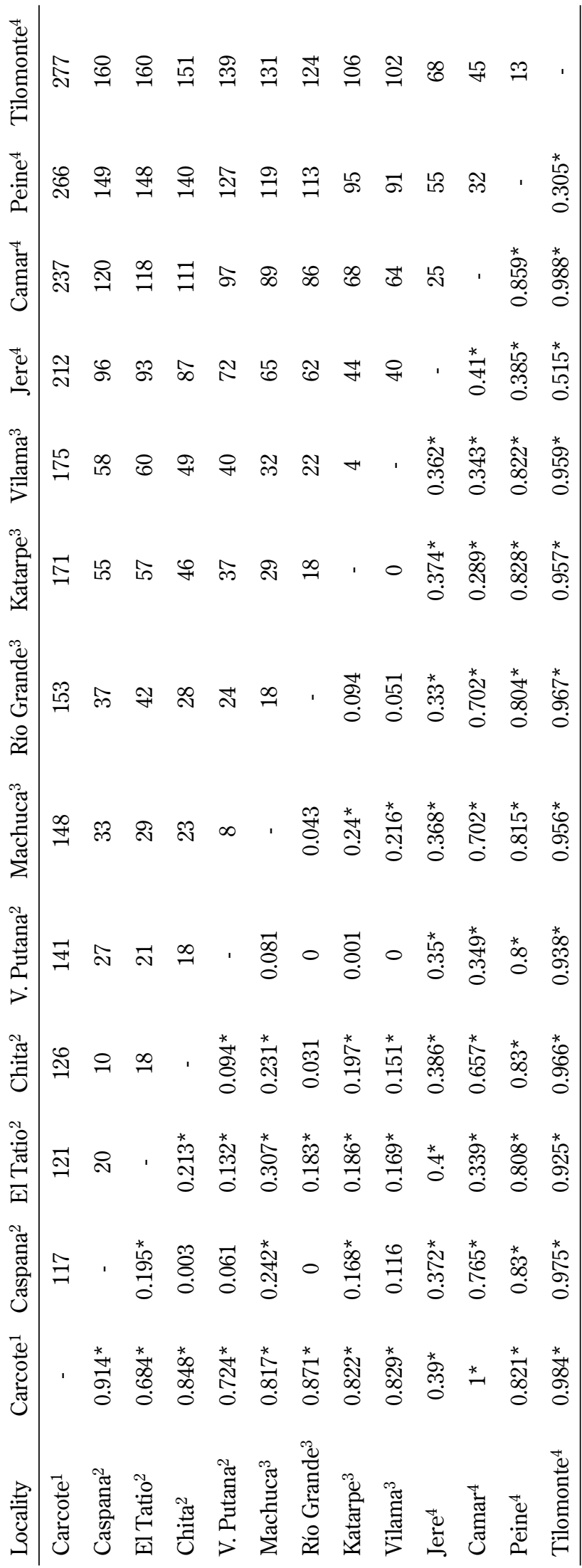




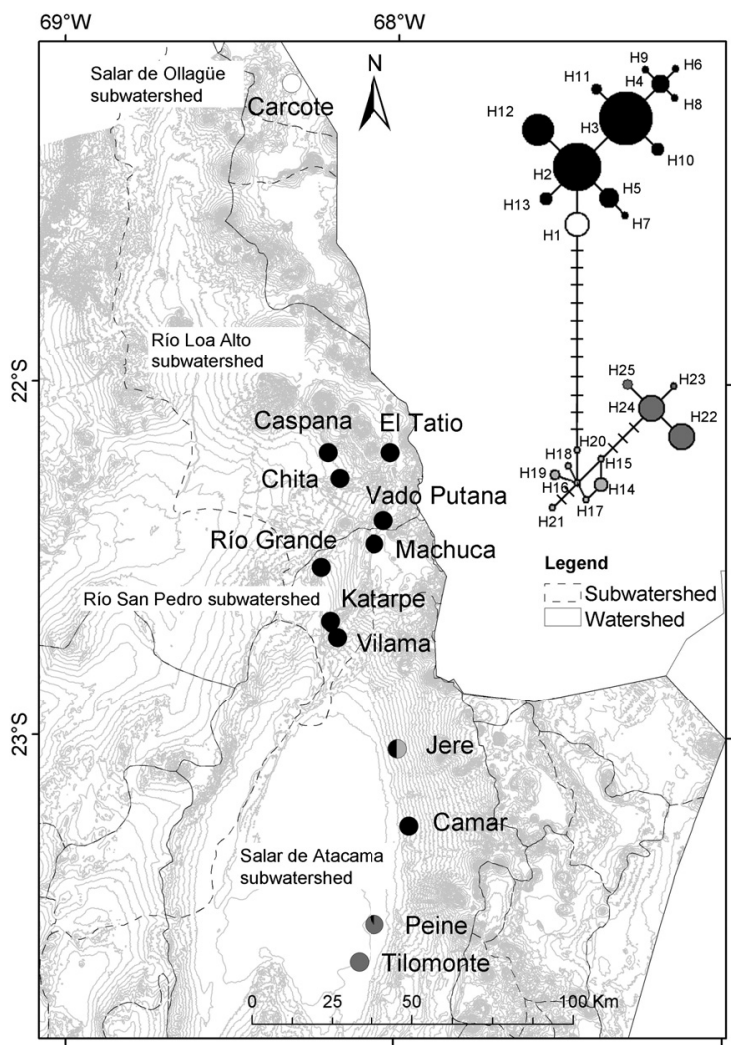

Fig. 3: Haplotype network constructed using the median-joining method for the 25 mitochondrial haplotypes found in 203 individuals of Rhinella spinulosa from Antofagasta Region. Colors of the localities (circles in the map) indicate the four divergent haplogroups corresponding to the structure found in the SAMOVA analysis. The size of each circle in the haplotype network is proportional to its frequency. The short transverse lines on the branches indicate the mutational steps between haplotypes.

Red de haplotipos construida utilizando el método median-joining para los 25 haplotipos mitocondriales encontrados en 203 individuos de Rhinella spinulosa de la Región de Antofagasta. Los colores de las localidades (círculos en el mapa) muestran los cuatro haplogrupos divergentes, los cuales corresponden a la estructura encontrada en el análisis SAMOVA. El tamaño de cada círculo en la red de haplotipos corresponde a la frecuencia haplotípica. Las líneas cortas sobre las ramas indican los pasos mutacionales inferidos entre haplotipos.

\section{TABLE 3}

Results for the components of the spatial analysis of molecular variance (SAMOVA, see Fig. 3) and molecular analysis of variance (AMOVA) with 10000 permutations, separating Rhinella spinulosa populations into watersheds and sub-watersheds. ${ }^{*} \mathrm{P}<0.05$.

Resultados de los componentes del análisis espacial de varianza molecular (SAMOVA, ver Fig. 3) y el análisis de varianza molecular (AMOVA) con 10000 permutaciones, separando a las poblaciones de Rhinella spinulosa según cuenca y subcuenca. ${ }^{\star} \mathrm{P}<0.05$.

\begin{tabular}{lccc}
\hline \multirow{2}{*}{ Source of variation } & \multicolumn{2}{c}{ AMOVA } & SAMOVA \\
\cline { 2 - 4 } & $\begin{array}{c}\text { Watershed } \\
\text { (three groups) }\end{array}$ & $\begin{array}{c}\text { Sub-watershed } \\
\text { (four groups) }\end{array}$ & (four groups) \\
\hline Among groups & $8.67^{*}$ & $35.99^{*}$ & $76.5^{\star}$ \\
Among populations between groups & $61.87^{*}$ & $35.97^{\star}$ & $3.02^{*}$ \\
Within population & 29.46 & $28.04^{*}$ & $20.48^{\star}$ \\
\hline
\end{tabular}


TABLE 4

Best model selection to explain the genetic differentiation of Rhinella spinulosa at different scales. $\triangle \mathrm{AICc}$ is the difference between the AICc value of the model and the minimum AICc value found among all the models. $r^{2}$ is the proportion of the genetic differentiation explained by each model. The best model for each route type and the Euclidean distance without the environmental variables are shown. (A) Between all localities. (B) For each sub-watershed. (C) Between the group 4 localities found with SAMOVA.

Selección del mejor modelo que explica la diferenciación genética de Rhinella spinulosa a diferentes escalas. $\Delta$ AICc corresponde a la diferencia entre el valor AICc de cada modelo y el valor mínimo de AICc encontrado entre todos los modelos. $\mathrm{r}^{2}$ es la proporción de la diferenciación genética explicada por cada modelo. Se muestran el mejor modelo para cada tipo de ruta y la distancia euclidiana sin las variables ambientales. (A) Entre todas las localidades. (B) Para cada subcuenca. (C) Entre las localidades del grupo 4 del análisis SAMOVA.

(A)

\begin{tabular}{lcccc}
\hline Routes & \multicolumn{1}{c}{ Variables } & AICc & $\Delta$ AICc & $\mathrm{r}^{2}$ \\
\hline Euclidean distance & Annual precipitation, altitude & -17.351 & 0 & $0.646(\mathrm{P}<0.0001)$ \\
Least slope & Annual precipitation, altitude & -12.364 & 4.987 & $0.622(\mathrm{P}<0.0001)$ \\
Based wetlands & Annual precipitation, altitude & -7.161 & 10.19 & $0.596(\mathrm{P}<0.0001)$ \\
Euclidean distance & & -10.032 & 25.343 & $0.588(\mathrm{P}<0.0001)$ \\
\hline
\end{tabular}

(B)

\begin{tabular}{|c|c|c|c|c|}
\hline Routes & Variables & $\mathrm{AICc}$ & $\triangle \mathrm{AICc}$ & $\mathrm{r}^{2}$ \\
\hline \multicolumn{5}{|l|}{ Río Loa Alto } \\
\hline Least slope route & $\begin{array}{l}\text { Annual precipitation, } \\
\text { annual mean temperature, altitude }\end{array}$ & -123.619 & 0 & $0.998(\mathrm{P}<0.001)$ \\
\hline Euclidean Distance & $\begin{array}{l}\text { Annual precipitation, } \\
\text { annual mean temperature, altitude }\end{array}$ & -122.494 & 1.125 & $0.998(\mathrm{P}<0.001)$ \\
\hline Wetland-based route & $\begin{array}{l}\text { Annual precipitation, } \\
\text { annual mean temperature, altitude }\end{array}$ & -122.071 & 1.547 & $0.997(\mathrm{P}<0.001)$ \\
\hline Euclidean Distance & & 3.168 & 126.786 & $0.079(\mathrm{P}=0.59)$ \\
\hline Río San Pedro & & $\mathrm{AICc}$ & $\Delta \mathrm{AICc}$ & $\mathrm{r}^{2}$ \\
\hline Wetland route & $\begin{array}{c}\text { Annual precipitation, } \\
\text { annual mean temperature, altitude }\end{array}$ & -111.198 & 0 & $0.989(\mathrm{P}=0.003)$ \\
\hline Euclidean distance & $\begin{array}{l}\text { Annual precipitation, } \\
\text { annual mean temperature, altitude }\end{array}$ & -110.854 & 0.344 & $0.989(\mathrm{P}=0.003)$ \\
\hline Least slope route & $\begin{array}{l}\text { Annual precipitation, } \\
\text { annual mean temperature, altitude }\end{array}$ & -105.831 & 5.367 & $0.974(\mathrm{P}=0.01)$ \\
\hline Euclidean Distance & & -2.183 & 109.015 & $0.749(\mathrm{P}=0.026)$ \\
\hline Salar de Atacama & & $\mathrm{AICc}$ & $\Delta \mathrm{AICc}$ & $\mathrm{r}^{2}$ \\
\hline Least slope route & $\begin{array}{l}\text { Annual precipitation, } \\
\text { annual mean temperature, altitude }\end{array}$ & -156.934 & 0 & $1(\mathrm{P}<0.001)$ \\
\hline Euclidean Distance & $\begin{array}{l}\text { Annual precipitation, } \\
\text { annual mean temperature, altitude }\end{array}$ & -141.578 & 15.357 & $1(\mathrm{P}<0.001)$ \\
\hline Wetland-based route & $\begin{array}{l}\text { Annual precipitation, } \\
\text { annual mean temperature, altitude }\end{array}$ & -110.856 & 46.079 & $0.999(\mathrm{P}<0.001)$ \\
\hline Euclidean Distance & & 18.455 & 175.39 & $0.031(\mathrm{P}=0.73)$ \\
\hline
\end{tabular}

(C)

\begin{tabular}{lcccc}
\hline Routes & Variables & AICc & $\Delta$ AICc & $\mathrm{r}^{2}$ \\
\hline Wetland-based route & Annual precipitation, altitude & -49.93 & 0 & $0.749(\mathrm{P}<0.0001)$ \\
Wetland-based route & Annual precipitation, temperature & -49.788 & 0.142 & $0.748(\mathrm{P}<0.0001)$ \\
Least slope route & Annual precipitation, altitude & -48.421 & 1.509 & $0.738(\mathrm{P}<0.0001)$ \\
Euclidean Distance & & -40.81 & 9.12 & $0.625(\mathrm{P}<0.0001)$ \\
\hline
\end{tabular}


Analysis at a small spatial scale, grouping populations by sub-watershed

We performed the small scale spatial analysis at the sub-watershed level because the AMOVA showed that sub-watersheds explained a greater amount of variance than watersheds (Table 3 ). Therefore, we analyzed the routes and variables that best explained the genetic differentiation within each sub-watershed. The Carcote locality was not included in these analyses, since it was the only locality in its sub-watershed.

The AIC showed that the best model in the Río Loa Alto sub-watershed included the variables: precipitation, temperature, altitude and least-slope route. The genetic differentiation explained for this model was high (99.8 \%; $\mathrm{P}<0.001)$ (Table 4B, Fig. 5A). However, separately these variables were not significant. The Euclidean distance had a low value and not significant (Table 4B).

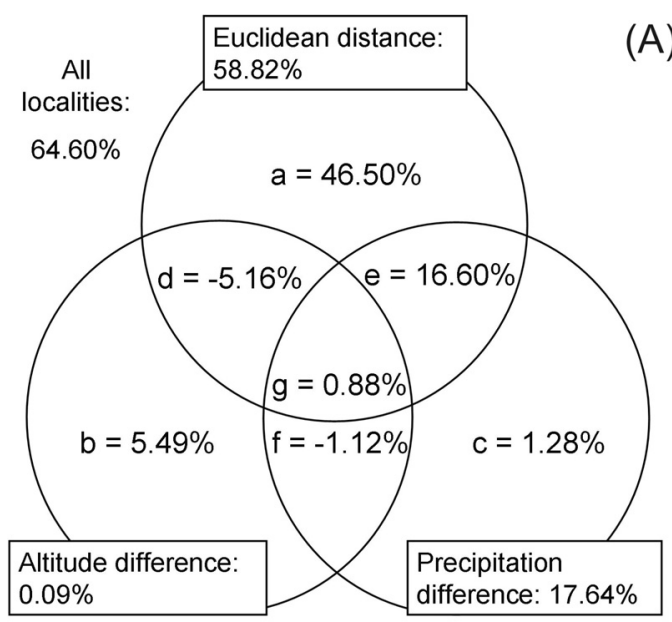

The AIC showed that the best model in the Río San Pedro sub-watershed included the variables: precipitation, temperature, altitude and wetland based route. The genetic differentiation explained for this model was high (98.9 \%; $\mathrm{P}=0.003)$. The variables temperature, altitude and wetland based route had values high and significant $(80.4 \%, 83.4$ $\%$ and $74.3 \%$ respectively), and are highly correlated, in contrast to precipitation (Fig. 5B). This model explains $28 \%$ more than the Euclidean distance (Table 4B).

The AIC showed that the best model in the Salar de Atacama sub-watershed included the variables: precipitation, temperature, altitude and least-slope route. The genetic differentiation explained for this model was $100 \%(\mathrm{P}<0.001)$. The variables temperature and altitude had values high and significant (55 $\%$ and $84.4 \%$, respectively) and also are highly correlated, unlike precipitation and least-slope

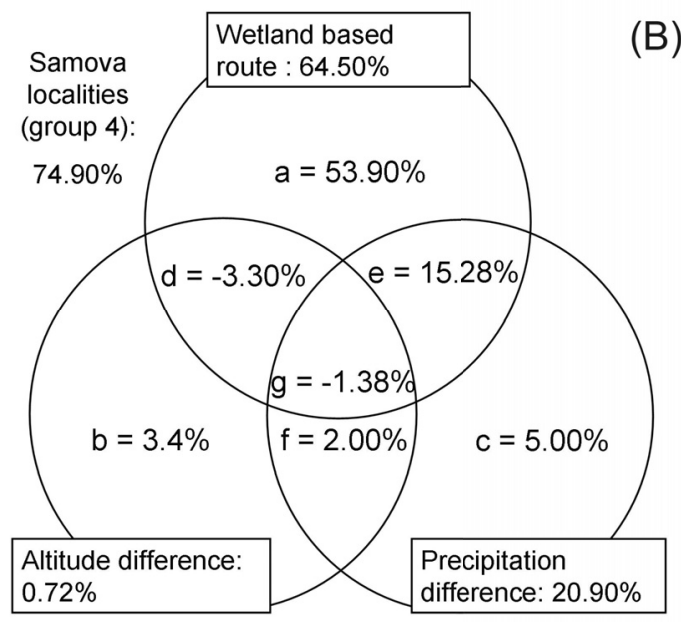

Fig. 4: The diagram shows the variation in $\mathrm{F}_{\text {st }}$ (dependent variable) as a function of three explanatory variables. The combined effects of variables are shown in $\mathrm{d}$, e, and $\mathrm{f}$. The individual effects of variables are shown in $\mathrm{a}, \mathrm{b}$, and $c$. The variation using the three variables is shown in $g$. The decomposition of the variation was performed with partial regressions, using linear models and considering the proportion of the variation explained. (A) Between all populations, explanatory variables: Euclidean distance, altitude and precipitation. The model explained $63 \%$ of the total variation. (B) Between SAMOVA localities (group 4), explanatory variables: wetland-based route, altitude and precipitation. The model explained $74.9 \%$ of total variation.

El diagrama muestra la variación en $\mathrm{F}_{\mathrm{st}}$ (variable dependiente) como una función de tres variables explicativas. Los efectos combinados de las variables se muestran en d, e y f. Los efectos individuales de las variables se muestran en a, b y c. La variación utilizando las tres variables se muestra en $\mathrm{g}$. La descomposición de las varianza fue realizada con regresiones parciales, utilizando modelos lineales y considerando la proporción de la varianza explicada. (A) Entre todas las poblaciones, variables explicativas: distancia euclidiana, altitud y precipitación. El modelo explicó un 63 \% de la varianza total. (B) Entre las localidades del grupo 4 de SAMOVA, variables explicativas: ruta basada en humedales, altitud y precipitación. El modelo explicó un $74.9 \%$ de la varianza total. 
route (Fig. 5C). The Euclidean distance had a low value and not significant (Table 4B).

In contrast to the results obtained using all populations, within sub-watersheds the variable Euclidean distance was not selected in the best explanatory model. Only in Río San Pedro sub-watershed this variable was important in explaining the genetic differentiation.

Analysis using the results of a spatial analysis of molecular variation

The SAMOVA showed that maximum variance was obtained with four groups: (1) Carcote; (2) Jere; (3) Peine and Tilomonte; (4) Caspana, Tatio, Chita, Vado Putana, Machuca, Río Grande, Katarpe, Vilama and Camar. Analyses that included landscape variables were performed using localities from group 4, because the other groups were formed by only

Río Loa Alto: $99.8 \%$

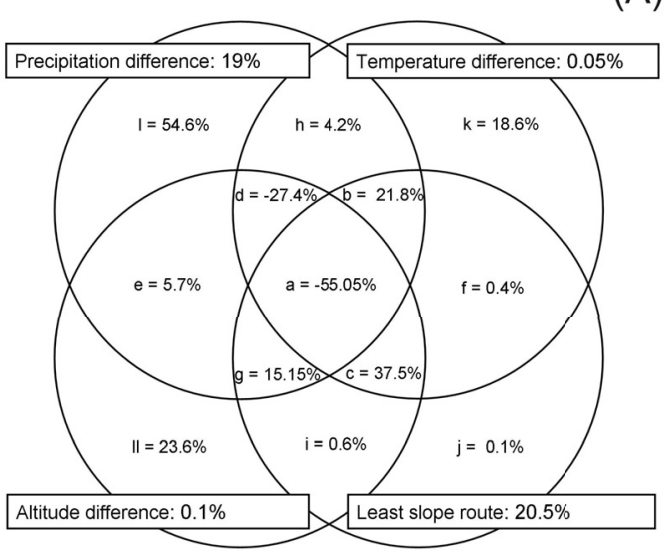

Salar de Atacama: $100 \%$

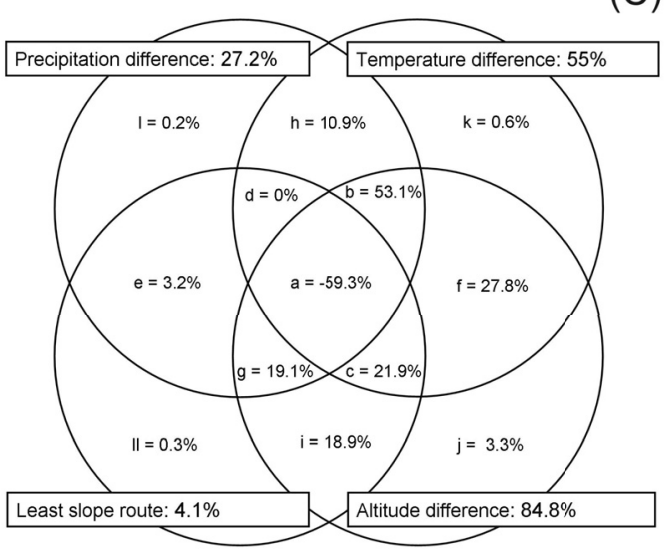

one or two localities. The genetic differentiation $\left(\mathrm{F}_{\mathrm{st}}\right)$ in this group was $0.219(\mathrm{P}=0.0001)$. The model with the lowest AIC value for the group 4 localities included wetland-based route, annual precipitation and altitude; it explained $74.9 \%$ of the genetic differentiation. However, according to AIC all the selected models were equivalent; hence it was not possible to determine the best model. Despite this, the annual precipitation variable was present in all the chosen models, whereas wetland-based route was present in the first two models (Table 4C). We determined the contribution of each variable by relating the response variable $\left(\mathrm{F}_{\mathrm{st}}\right)$ to the predictive variables; altitude, annual precipitation and wetland-based route which had values of 0.72 $\%, 20.97 \%$ and $64.50 \%$, respectively (Fig. 4B). Partial regressions showed that the greatest proportion of differentiation was explained by the wetland-based route alone $\left(r^{2}=53.9\right)$

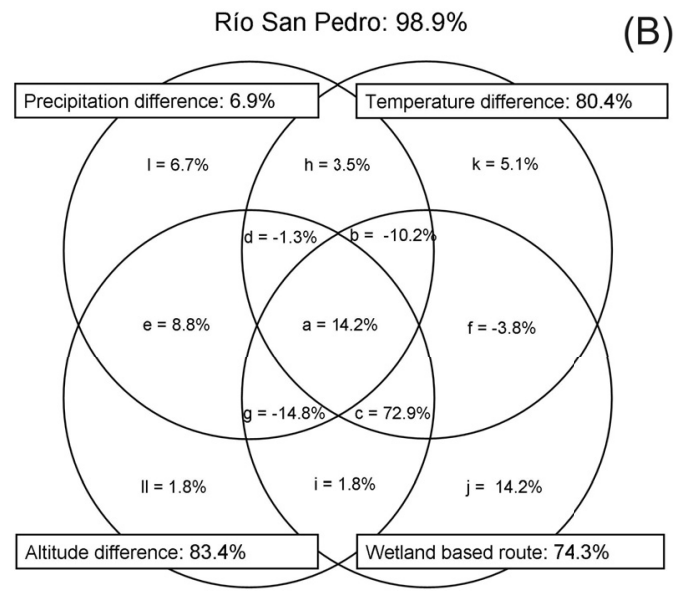

Fig. 5: Similar procedures described in the legend of Fig. 4, however the diagram shows the variation in $\mathrm{F}_{\text {st }}$ (dependent variable) as a function of four explanatory variables (A) in the Río Loa Alto, (B), Río San Pedro and (C) Salar de Atacama subwatersheds.

Procedimientos similares a los descritos en la leyenda de la Fig. 4, sin embargo, el diagrama muestra la variación en $\mathrm{F}_{\mathrm{st}}$ (variable dependiente) como una función de cuatro variables explicativas en las subcuencas (A) Río Loa Alto, (B) Río San Pedro y (C) Salar de Atacama. 
and the overlap of wetland-based route and precipitation. The Euclidean distance had a high and significant (Table 4C).

\section{DISCUSSION}

Geographic distance may be a factor of little importance in maintaining genetic structure compared to other features of the environment which may limit dispersal, such as climatic gradients and topography changes (Kozak et al. 2008). Landscape analyses provide a powerful framework for directly analyzing relationships between population processes and landscape structure at relevant spatial and temporal scales (Segelbacher et al. 2010). We found that at a large spatial scale, the genetic differentiation of $R$. spinulosa has been strongly influenced by isolation by distance. The isolation by distance pattern was expected, as patterns related to landscape features would dilute in a biogeographic or phylogeographic context (over $100 \mathrm{~km}$ ). Thus, distance is the only relevant factor in genetic differentiation at a large scale; however, the isolation by distance model does not fit fine-scale genetic patterns (Stepien et al. 2007, Koscinski et al. 2009).

According to our results, landscape features only explained $5.8 \%$ more of the total genetic differentiation at a large scale (all population considered). We observed that annual precipitation is an important factor explaining population genetic differentiation, although the overlap detected between this variable and Euclidean distance did not allow us to clarify the effects of each of them on genetic differentiation. This overlap may be caused because localities with similar precipitation levels are closer. The precipitation alone only explains $1.28 \%$ of genetic differentiation, in comparison to Euclidean distance that explains $46.5 \%$ (Fig. 4A). Thus at a large scale, the pattern predominant found, was isolation by distance.

At a smaller scale, sub-watersheds explained a greater percentage of the genetic variance than watersheds did, suggesting a strong association between local geographic structure and genetic structure. At sub-watersheds level, the genetic differentiation was explained by environmental and landscape variables. In two of three sub-watersheds (Río San
Pedro and Salar de Atacama) the altitude and temperature explains a high degree of genetic differentiation. It is difficult to know the importance of each on the genetic differentiation due to the high correlation between them in both sub-watersheds. Interestingly, altitude was also chosen in the large scale model; however, it did not have as much importance as it did at the subwatersheds level.

In Río San Pedro sub-watershed, we observed low genetic differentiation among localities, in presence of remarkable differences in altitude. This result supports the idea that sporadic floods could allow contact between nearby localities (Méndez et al. 2004, Correa et al. 2010). The Chilean Altiplano has been in a period of drought since the late Holocene (Latorre et al. 2003), although occasional rains have been reported driving to catastrophic floods allowing the mixing of populations (Niemeyer \& Cereceda 1984). In our model, the wetland-based route, was a model component preferred over Euclidian distances model (Table 4B, Fig. 5B). Thus, in this sub-watershed floods along to altitude differences among localities could explain the connectivity observed among populations across wetland route.

In the Salar de Atacama sub-watershed, we found a high level of genetic differentiation among populations with low temperature and altitude differences $(<300 \mathrm{~m})$. In this subwatershed the populations are located at minor differences of altitude in comparison to other sub-watershed; therefore flood events could not promote the connectivity among populations. According with this idea, we did not find a relationship between genetic differentiation and probable routes of dispersal (i.e. wetland, Euclidian and least slope routes). Thus, considering the low vagility of $R$. spinulosa, we do not expect contact among populations. This pattern could explain the high divergence observed between close populations (i.e. Peine and Tilomonte) and support a model of peripatric differentiation as proposed by Correa et al. (2010).

In the Río Loa Alto sub-watershed the model that considered all variables was significant (Table 4B), however, when each variable was considered individually, we did not observed significance in any variable. However, when 


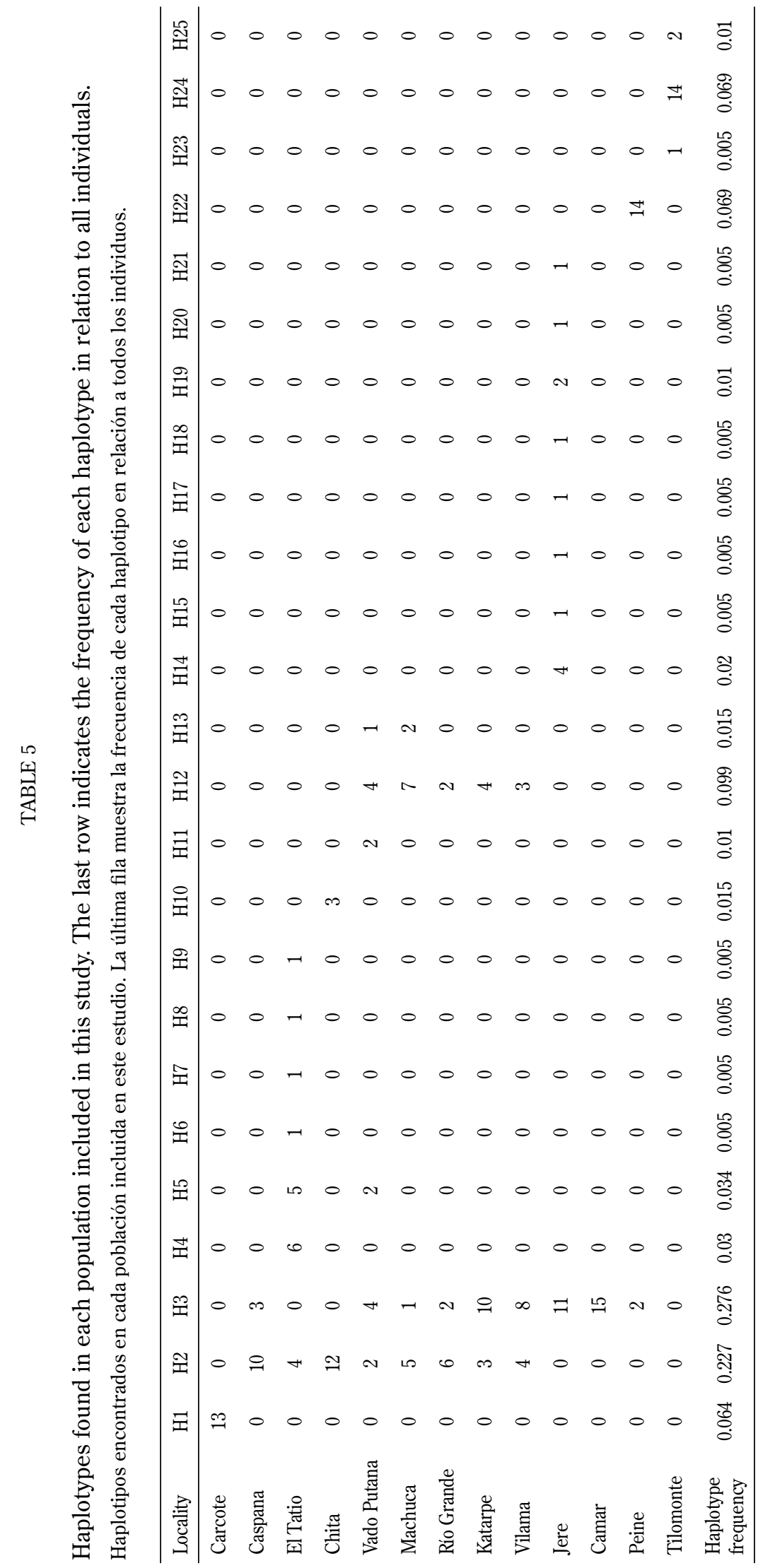


these populations are incorporated in the SAMOVA analysis, it was possible to find a relationship among these populations with landscape variables, being concordant with the model that considered all variables together.

The group analyzed using the results of SAMOVA showed that annual precipitation explained the genetic differentiation, in agreement with the analysis of all populations. However, the wetland-based route was selected instead of the Euclidean distance. We suggest that the wetland-based route is related to a recent diversification pattern, as is shown by localities with little genetic differentiation. This pattern was also detected by Correa et al. (2010), suggesting that it could be related to an early divergence among these populations. The wetland-based route is based on a stepping stone model. This pattern may be related to changes in the precipitation regime in the Altiplano zone, which have had effects on the expansion and contraction of the vegetation since the end of the Pleistocene and during all of the Holocene (Betancourt et al. 2000, Latorre et al. 2006, Quade et al. 2008). Wetlands are the only appropriate habitat for $R$. spinulosa; the desert is much more hostile for this species. For this reason, we expected this route to be selected in our model, because the ability of amphibians to move between isolated populations is largely dependent on the suitability of habitat among populations (Marsh et al. 2001).

Our study shows that incorporating landscape features in a biogeographic and small scale context produces a greater understanding of the processes occurring at different levels. While between all localities Euclidean distance and annual precipitation were related to genetic differentiation at a larger spatial scale, altitude, temperature and wetland based route, were related at a smaller spatial scale. Probably the same variables appear to be related to events that occurred in a more recent time. The altitude difference has been related with genetic differentiation in amphibians inhabiting mountain regions, showing high levels of population differentiation (Funk et al. 2005, Spear et al. 2005). In this case, it would also be a relevant factor, that does not allow the dispersal of $R$. spinulosa, as is shown in nearby populations (Peine and Tilomonte). This effect will be reduced when other factors can encourage the dispersion. The temperature, in $R$. spinulosa, could act as a potential barrier to dispersal, determining, along with altitude, local genetic differentiation. According to this idea, Méndez \& Correa-Solis (2009) reported local adaptation to temperature in $R$. spinulosa, which ultimately could lead to population differentiation.

The landscape genetic approach allowed us to understand the importance of landscape and environmental features in the history of diversification of populations of $R$. spinulosa in the Altiplano. Although $R$. spinulosa is considered a species of least concern by the International Union for the Conservation of Nature (Angulo 2004), we believe that it is a challenge to understand the history of this species in the high altitude wetlands. Recently, wetlands in arid and semiarid zones are endangered by water extraction and pollution due mainly to mining activity. Understanding the dynamics of this ecosystem can help us to appreciate the importance of conserving these unique places.

ACKNOWLEDGEMENTS: This work was supported by grants FONDECYT 1061256, 1100558, and DOMEYKO Biodiversidad Iniciativa Transversal 1, Universidad de Chile. The Servicio Agrícola y Ganadero supplied collecting permits; Resolutions number 3085/2000, $2105 / 2004$, and $13 / 2006$. We thank Lorenzo Campos, Luis Pastenes, Pamela Morales, Daniel Montaner, Claudio Correa, Cristián Estades, Rodolfo Gajardo and people of Departamento de Biologia Geral of the Universidad Federal de Goiás. Gallardo C.E. thanks Becas de Estadías Cortas de Investigación de la Vicerrectoría de Asuntos Académicos de la Universidad de Chile.

\section{LITERATURA CITADA}

ANGULO A, I DE LA RIVA, J CÓRDOVA-SANTA GADEA, A VELOSO, H NÚNEZ, C ÚBEDA, E LAVILLA \& B LOTTO (2004) Rhinella spinulosa. IUCN Red List of Threatened Species. Version 2010.1. URL: http://www.iucnredlist.org (accessed January 03, 2011).

ACEITUNO P (1997) Aspectos generales del clima en el altiplano sudamericano. In: Charrier $\mathrm{R}, \mathrm{P}$ Aceituno, M Castro, A Llanos \& LA Raggi (eds) Altiplano ciencia y conciencia de los Andes: 63-69. Actas del II Simposio Internacional de Estudios Altiplánicos, Santiago, Chile.

ADDINSOFT (2009) XLSTAT 2010 version 2.03. Paris, France.

ANDERSON MJ \& NA GRIBBLE (1998) Partitioning the variation among spatial, temporal and environmental components in a multivariate dataset. Australian Journal of Ecology 23: 158167. 
ARROYO MTK, FA SQUEO, J ARMESTO \& C VILLAGRÁN (1988) Effects of aridity on plant diversity in the northern Chilean Andes: Results of a natural experiment. Annals of the Missouri Botanical Garden 75: 55-78.

BANDELT HJ, P FORSTER \& A RÖHL (1999) Medianjoining networks for inferring intraspecific phylogenies. Molecular Biology and Evolution 16: 37-48.

BETANCOURT JL, C LATORRE, JA REACH, J QUADE \& KA RYLANDER (2000) A 22000-year record of monsoonal precipitation from northern Chile's Atacama Desert. Science 289: 1542-1546.

BROQUET T, N RAY, E PETIT, JM FRYXELL \& F BUREL (2006) Genetic isolation by distance and landscape connectivity in the American marten (Martes Americana). Landscape Ecology 21: 877889.

BURNHAM KP \& DR ANDERSON (2002) Model selection and multimodel inference. A practical information -theoretical approach. Second edition. Springer, New York.

CASTILLO $\mathrm{G}$, M CASTRO, M BAHAMONDES \& V LORCA (1997) Caracterización de la calidad sanitaria de aguas de bofedales y vegas del área andina chilena. In: Charrier R, P Aceituno, M Castro, A Llanos \& LA Raggi (eds) Altiplano ciencia y conciencia de los Andes: 117-123. Actas del II Simposio Internacional de Estudios Altiplánicos, Santiago, Chile.

CEI JM (1962) Batracios de Chile. Ediciones Universidad de Chile, Santiago, Chile.

CLARK R, W BROWN, R STECHERT \& K ZAMUDIO (2008) Integrating individual behaviour and landscape genetics: The population structure of timber rattlesnake hibernacula. Molecular Ecology 17: 719-730.

CORREA C, L PASTENES, A VELOSO, M SALLABERRY \& MA MÉNDEZ (2010) Phylogeography of Rhinella spinulosa (Anura: Bufonidae) in northern Chile. Amphibia-Reptilia 31: 85-96.

DAYTON GH \& LA FITZGERALD (2006) Habitat suitability models for desert amphibians. Biological Conservation 132: 40-49.

DINIZ-FILHO JAF, MPC TELLES, SL BONATTO, E EIZIRIK, THR DE FREITAS et al. (2008) Mapping the evolutionary twilight zone: Molecular markers, populations and geography. Journal of Biogeography 11: 753-763.

DUPANLOUP I, S SCHNEIDER \& L EXCOFFIER (2002) A simulated annealing approach to define the genetic structure of populations. Molecular Ecology 11: 2571-2581.

ESPINOZA RE \& S QUINTEROS (2008) A hot knot of toads: Aggregation provides thermal benefits to metamorphic Andean toads. Journal of Thermal Biology 33: 67-75.

ESRI (2006) ArcGIS version 9.2. Environmental Systems Research Institute, Redlands, California, USA.

EXCOFFIER L, G LAVAL \& S SCHNEIDER (2005) Arlequin ver. 3.0: An integrated software package for population genetics data analysis. Evolutionary Bioinformatics Online 1: 47-50.

FAÚNDEZ L \& M ESCOBAR (2006) Estudio de los sistemas vegetacionales azonales hídricos del altiplano. Biota Gestión y Consultorías Ambientales Limitada, Santiago, Chile.

FUNK CH, M BLOUIN, P CORN, B MAXELL, D PILLIOD, S AMISH \& F ALLENDORF (2005) Population structure of Columbia spotted frogs
(Rana luteiventris) is strongly affected by the landscape. Molecular Ecology 14: 483-496.

GUILLOT G, A ESTOUP, F MORTIER \& J COSSON (2005) A spatial statistical model for landscape genetics. Genetics 170: 1261-1280.

HALL T (1999) Bioedit: A user-friendly biological sequence alignment editor and analysis program for windows 95/98/NT, version 5.0.9, 2001. Nucleic Acids Symposium Series 41: 95-98.

HIJMANS RJ, SE CAMERON, JL PARRA, PG JONES \& A JARVIS (2005) Very high resolution interpolated climate surfaces for global land areas. International Journal of Climatology 25: 1965-1978.

HULL J, A HULL, J SACKS, J SMITH \& E HOLLY (2008) Landscape characteristics influence morphological and genetic differentiation in a widespread raptor (Buteo jamaicensis). Molecular Ecology 17: 810-824.

KOSCINSKI D, AG YATES, P HANDFORD \& SC LOUGHEED (2009) Effects of landscape and history on diversification of a montane, stream-breeding amphibian. Journal of Biogeography 36: 255-265.

KOZAK K, C GRAHAM \& J WIENS (2008) Integrating GISbased environmental data into evolutionary biology. Trends in Ecology and Evolution 23: 141-148.

LAMBRINOS JG \& CC KLEIER (2003) Thermoregulation of juvenile Andean Toads (Bufo spinulosus) at $4300 \mathrm{~m}$. Journal of Thermal Biology 28: $15-19$

LATORRE C, JL BETANCOURT, KA RYLANDER, J QUADE \& O MATTHEI (2003) A vegetation history from the arid prepuna of northern Chile $\left(22-23^{\circ} \mathrm{S}\right)$ over the last 13500 years. Palaeogeography, Palaeoclimatology, Palaeoecology 194: 223-246.

LATORRE C, JL BETANCOURT \& MTK ARROYO (2006) Late Quaternary vegetation and climate history of a perennial river canyon in the Río Salado basin $\left(22^{\circ} \mathrm{S}\right)$ of Northern Chile Quaternary Research 65: 450-466.

LEGENDRE P \& L LEGENDRE (1998) Numerical ecology. Second english edition. Elsevier Science, Amsterdam.

MANEL S, M SCHWARTZ, G LUIKART \& P TABERLET (2003) Landscape genetics: Combining landscape ecology and population genetics. Trends in Ecology and Evolution 18: 189-197.

MANLY BFJ (1985) The statistics of natural selection. Chapman and Hall, London.

MARSH DM \& PC TRENHAM (2001) Metapopulation dynamics and amphibian conservation. Conservation Biology 15: 40-49.

MÉNDEZ MA \& M CORREA-SOLÍS (2009) Divergence in morphometric and life history traits in two thermally constrasting andean populations of Rhinella spinulosa (Anura: Bufonidae). Journal of Thermal Biology 34: 342-347.

MÉNDEZ M, E SOTO, C CORREA, A VELOSO, E VERGARA, M SALLABERRY \& P ITURRA (2004) Diferenciación morfológica y genética entre poblaciones chilenas de Bufo spinulosus (Anura: Bufonidae). Revista Chilena de Historia Natural 77: 559-567.

MICHELS E, K COTTENIE, L NEYS, K DE GELAS, P COPPIN \& L DE MEESTER (2001) Geographical and genetic distances among zooplankton populations in a set of interconnected ponds: A plea for using GIS modeling of the effective geographical distance. Molecular Ecology 10: 1929-1938. 
NIEMEYER H \& P CERECEDA (1984) Hidrografía de Chile. Colección de geografía de Chile, Tomo VIII. Instituto Geográfico Militar, Santiago, Chile.

QUADE J, JA RECH, JL BETANCOURT, C LATORRE, B QUADE, K AASEN-RYLANDER \& T FISHER (2008) Paleowetlands and regional climate change in the central Atacama Desert, northern Chile. Quaternary Research 69: 343-360.

RANGEL TFLVB, JAF DINIZ-FILHO \& LM BINI (2006) Towards an integrated computational tool for spatial analysis in macroecology and biogeography. Global Ecology and Biogeography 15: 321-327.

ROHLF FJ (2000) NTSYSpc: Numerical taxonomy and multivariate analysis system. Version 2.1. Exeter Publishing, Ltd., Setauket, NY.

ROZAS J, JC SANCHEZ-DELBARRIO, X MESSEGUER \& R ROZAS (2003) DnaSP, DNA polymorphism analyses by the coalescent and other methods. Bioinformatics 19: 2496-2497.

SALAZAR C (1997) Hidrología del sector altiplánico chileno. In: Charrier R, P Aceituno, M Castro, A Llanos \& LA Raggi (eds) Altiplano ciencia y conciencia de los Andes: 71-77. Actas del II Simposio Internacional de Estudios Altiplánicos, Santiago, Chile.

SEGELBACHER G, SA CUSHMAN, BK EPPERSON, MJ FORTIN, O FRANCOIS et al. (2010) Applications of landscape genetics in conservation biology: Concepts and challenges. Conservation Genetics 11: 375-385.

SEPPÄ P \& A LAURILA (1999) Genetic structure of island populations of the anurans Rana temporaria and Bufo bufo. Heredity 82: 309-317.

SPEAR SF, CH PETERSON, M MATOCQ \& A STORFER (2005) Landscape genetics of the blotched tiger salamander (Ambystoma tigrinum melanostictum). Molecular Ecology 14: 2553-2564.

STATSOFT INC (2001) STATISTICA (data analysis software system). Version 6.0. StatSoft, Inc., Tulsa, OK.

Associate Editor: Marco Lardies

Received January 18, 2011; accepted August 3, 2011
STEPIEN CA, DJ MURPHY \& RM STRANGE (2007) Broad to fine-scale population genetic patterning in the smallmouth bass Micropterus dolomieu across the Laurentian Great Lakes and beyond: An interplay of behaviour and geography. Molecular Ecology 16: 1605-1624.

STORFER A, MA MURPHY, JS EVANS, CS GOLDBERG, S ROBINSON et al. (2007) Putting the landscape in landscape genetics. Heredity 98 : 128-142.

TELLES MPC \& JAF DINIZ-FILHO (2005) Multiple Mantel tests and isolation-by-distance, taking into account long-term historical divergence. Genetic and Molecular Research 4: 742-748.

TELLES MPC, JAF DINIZ-FILHO, RP BASTOS, TN SOARES, LD GUIMARAES \& LP LIMA (2007) Landscape genetics of Physalaemus cuvieri in Brazilian Cerrado: Correspondence between population structure and patterns of human occupation and habitat loss. Biological Conservation 139: 37-46.

THOMPSON JD, DG HIGGINS \& TJ GIBSON (1994) CLUSTAL W: Improving the sensitivity of progressive multiple sequence alignment through sequence weighting, position specific gap penalties and weight matrix choice. Nucleic Acids Research 22: 4673-4680.

VELOSO A \& J NAVARRO (1988) Lista sistemática y distribución geográfica de anfibios y reptiles de Chile. Bollettino del Museo Regionale di Scienze Naturali di Torino 6: 481-539.

VIDAL V (2009) Variación fenotípica y capacidad de dispersión de post-metamórficos de Rhinella spinulosa en la localidad de Farellones. Degree thesis, Facultad de Ciencias, Universidad de Chile, Santiago.

WIENS JA (2001) The landscape context of dispersal. In: Colbert J, E Danchin, AA Dhondt \& JD Nichols (eds) Dispersal: 96-109. Oxford University Press, New York. 